DOI: 10.46340/eujem.2020.6.6.9

\title{
Maksym Bespalov
}

ORCID ID: https://orcid.org/0000-0002-5575-8455

Academician Yuriy Bugay International Scientific and Technical University, Kyiv, Ukraine

\section{IMPROVING THE EFFECTIVENESS OF FISCAL REGIONAL POLICY IN UKRAINE}

The article examines fiscal regional policy and suggests ways to increase its effectiveness. The importance of fiscal regional policy is outlined and its basic principles of functioning are determined. The incomes of local budgets and their dynamics are analyzed, and the structure of sources of formation of a revenue part of local budgets is also defined. The directions of increasing local budgets' incomes based on the analysis are substantiated. It is substantiated that the increase of the revenue part of local budgets requires the solution of certain general problems that will contribute to the growth of their revenues not for the expense of intergovernmental transfers, but for the expense of increasing of the level of fiscal relations subjects' responsibility. The directions to increase the efficiency of regional fiscal policy's functioning are offered taking into account principles of regional fiscal policy.

Key words: local budgets, decentralization, fiscal regional policy, local budget revenues, intergovernmental transfers.

Formulation of the problem. Globalization challenges, exacerbation of resource use in the face of ever-increasing needs of the population proves the feasibility of a decentralized way of managing national economies to better meet the existing socio-economic and environmental needs of the population of specific regions. The experience of European countries has also proved the validity and feasibility of introducing decentralization of power management, in particular financial decentralization while maintaining the unity and integrity of the state system ${ }^{1}$. Ukraine has not become an exception and, in accordance with the set goals, taking into account the European experience, has started reforming public administration, including fiscal administration, in the direction of decentralization, starting in 2014. This, in turn, leads to an in-depth study of the improving experience the effectiveness of fiscal regional policy.

Analysis of recent research and publications. Among Ukrainian scholars studying the issues of regional development in the context of decentralization of power, including fiscal policy at the regional level, the works of those authors should be noted: Z. Varnaliy, N. Vakhovska ${ }^{2}$ A. Grechko, O. Kyrylenko, A Krysovaty, M. Kuzhelev ${ }^{3}$, I. Lunina, V. Melnyk, V. Oparin, V. Rodchenko ${ }^{4}$, L. Tarangul, S. Tulchynska ${ }^{5}$, V. Fedosov, L. Fedorishina ${ }^{6}$, O. Shabliy, I. Chugunov, S. Yuriy and many others, which indicates the importance and necessity of further research on this issue.

At the same time, the issues of fiscal policy at the regional level in the direction of improving its efficiency remain relevant and unresolved, which leads to further research in this direction.

\footnotetext{
${ }^{1}$ Тульчинська, С.О. (2009). Інтелектуально-інновачійна модернізація економіки Украйни: теоретикометодологічні аспекти. Київ, НТУУ «КПІ», 241.

2 Вахновська, Н.А. (2018). Фіскальна політика в контексті фінансової конвергенції соціально-економічного розвитку регіонів України. Економічний форум, 2, 271-276.

${ }^{3}$ Кужелєв, М.О., Нечипоренко, А.В. (2019). Фінансові інструменти стимулювання регіонального розвитку: практика використання в Україні. Київ, 224.

${ }^{4}$ Родченко, В.Б., Прус, Ю.І. (2016). Вплив реформи фіскальної децентралізації на місцеві бюджети України. Сочіальна економіка, 1, 59-68.

5 Тульчинська, С.О. (2014). Перспективи та домінанти розвитку інтелектуально-інноваційної системи регіонів України. Херсон: ПП Вишемирський В.С., 210.

${ }^{6}$ Федоришина, Л.І., Жмурко, І.В. (2016). Соціальна і фіскальна політика держави: вплив на регіональному рівні. Глобальні та національні проблеми економіки, 12, 468-473.
} 
The purpose of the article is a detailed review of fiscal regional policy and suggestion if the ways to increase its effectiveness. To achieve this goal, the author outlined the importance of fiscal regional policy and identified its basic principles of operation; local budget revenues and their dynamics are analyzed; the directions on increase of local budgets incomes are substantiated; measures to increase the effectiveness of fiscal regional policy are proposed.

Research results. Fiscal regional policy and its boundaries are set by the state within the state fiscal policy. The main efforts of fiscal regional policy and its directions coincide with the state and are to ensure the economic development of economic entities by regulating taxes and budget expenditures at various levels. At the regional level, fiscal regulation is carried out through the change in the prescribed manner of certain tax rates on local taxes and fees, as well as through funding from local budgets for socio-economic activities at the local level. The experience of many European countries has shown that solving socio-economic problems on the ground is more efficient and timelier in the long run, which is one of the advantages of financial decentralization. It is at the regional level that it is possible to take into account the existing features and potential opportunities for a more rational use of local financial resources. Fiscal regional policy is carried out in accordance with national principles and approaches of fiscal administration. Among the principles of fiscal regional policy are the following principles:

- systematic, which provides for the tightness of the relationship of the entire fiscal system, as well as its tax and budget system;

- territorial justice, which provides for the establishment of a rational and optimal relationship between the ability to pay taxes of the subjects of a particular region and the level of tax burden of the business sector in the region of the respective territorial level;

- local peculiarity, which takes into account objective exogenous factors and special conditions that directly affect the subjects of regional taxation and the functioning of the business sector;

- regional equality, which provides for the provision of equal tax conditions for taxpayers of the regions, taking into account the legally established special conditions for the priority development of territories;

- adequacy, which is based on taking into account the adequacy of the expenditure and revenue parts of local budgets;

- stability, which provides the optimality and sustainability of fiscal legislation and changes to it, including within the established limits at the regional level;

- flexibility, which provides for a timely response to changes in business conditions and the possibility of rapid changes in the prescribed manner for taxation and expenditures of local budgets;

- regional efficiency, which provides rational and efficient use of financial resources towards socioeconomic and ecological regional development.

Let's analyze the revenues of local budgets since 2015, which was the beginning of the reformatting of the fiscal system in the direction of financial decentralization. Table 1 presents the structure of the revenue side of local budgets. Despite decentralization, unfortunately almost half of local budget revenues continue to be official transfers. However, during the study period, their share gradually decreases from $59.1 \%$ in the structure of income in 2015 to $46.4 \%$ in 2019. That is, the decrease in transfer income over five years is $12.7 \%$. Also, non-tax revenues tend to decrease in the structure of local budget revenues from $6.9 \%$ in 2015 to $4.7 \%$ in 2019 , ie by $2.2 \%$. The opposite trend, namely the increase in the share of local budget revenues, has tax revenues, namely from $33.4 \%$ to $48.3 \%$, i.e. the share of local budget revenues from taxes increased by $14.9 \%$ in five years.

The structure of sources of formation of the revenue side of local budgets is shown in Fig. 1.

Amendments to the Budget code of Ukraine and the Tax code of Ukraine have expanded the existing revenue base of local budgets by securing stable sources (income tax and personal income tax) for local budgets; redistribution of the single and environmental taxes, fees for the provision of administrative services, state duties, property tax, expanding its tax base by cars with a large engine capacity and commercial real estate. New subventions were introduced from the state budget to the budgets of local authorities to cover expenditures on state-delegated powers - medical, educational, and a subvention for the training of workers. Also, amendments to the Tax Code of Ukraine increase the level of fiscal independence of local authorities in relation to local fees and taxes by granting the right to independently determine tax rates and establish benefits for their payment ${ }^{1}$.

\footnotetext{
${ }^{1}$ Алескерова, Ю. В. (2016). Фіскальний механізм соціально-економічної сфери як складова частина фінансового механізму держави. Причорноморські економічні студї, 3, 98-101.
} 
Dynamics and structure of the Ukraine local budgets' revenue part for 2015-2019, UAH billion

\begin{tabular}{|l|c|c|c|c|c|}
\hline \multicolumn{1}{|c|}{$\begin{array}{c}\text { The structure of local budget } \\
\text { revenues }\end{array}$} & 2015 & 2016 & 2017 & 2018 & 2019 \\
\hline Tax revenues, UAH billion & 98,2 & 146,9 & 201 & 232,5 & 270,5 \\
\hline$\%$, to income & 33,4 & 40,1 & 40,0 & 41,4 & 48,3 \\
\hline Non-tax revenues, UAH billion & 20,2 & 21,9 & 25,9 & 28,0 & 26,1 \\
\hline$\%$, to income & 6,9 & 6,0 & 5,2 & 5,0 & 4,7 \\
\hline $\begin{array}{l}\text { Income from capital transactions, } \\
\text { UAH billion }\end{array}$ & 1,6 & 1,4 & 1,9 & 2,1 & 2,9 \\
\hline$\%$, to income & 0,5 & 0,4 & 0,4 & 0,4 & 0,5 \\
\hline Trust funds, UAH billion & 0,4 & 0,5 & 0,6 & 0,7 & 0,6 \\
\hline$\%$, to income & 0,1 & 0,1 & 0,1 & 0,1 & 0,1 \\
\hline Official transfers, UAH billion & 174,0 & 195,4 & 272,6 & 298,9 & 260,3 \\
\hline$\%$, to income & 59,1 & 53,4 & 54,3 & 53,2 & 46,4 \\
\hline Total & 294,4 & 366,1 & 502,0 & 562,2 & 560,4 \\
\hline , total & 100,0 & 100,0 & 100,0 & 100,0 & 100,0 \\
\hline
\end{tabular}

Source: compiled by the author according to

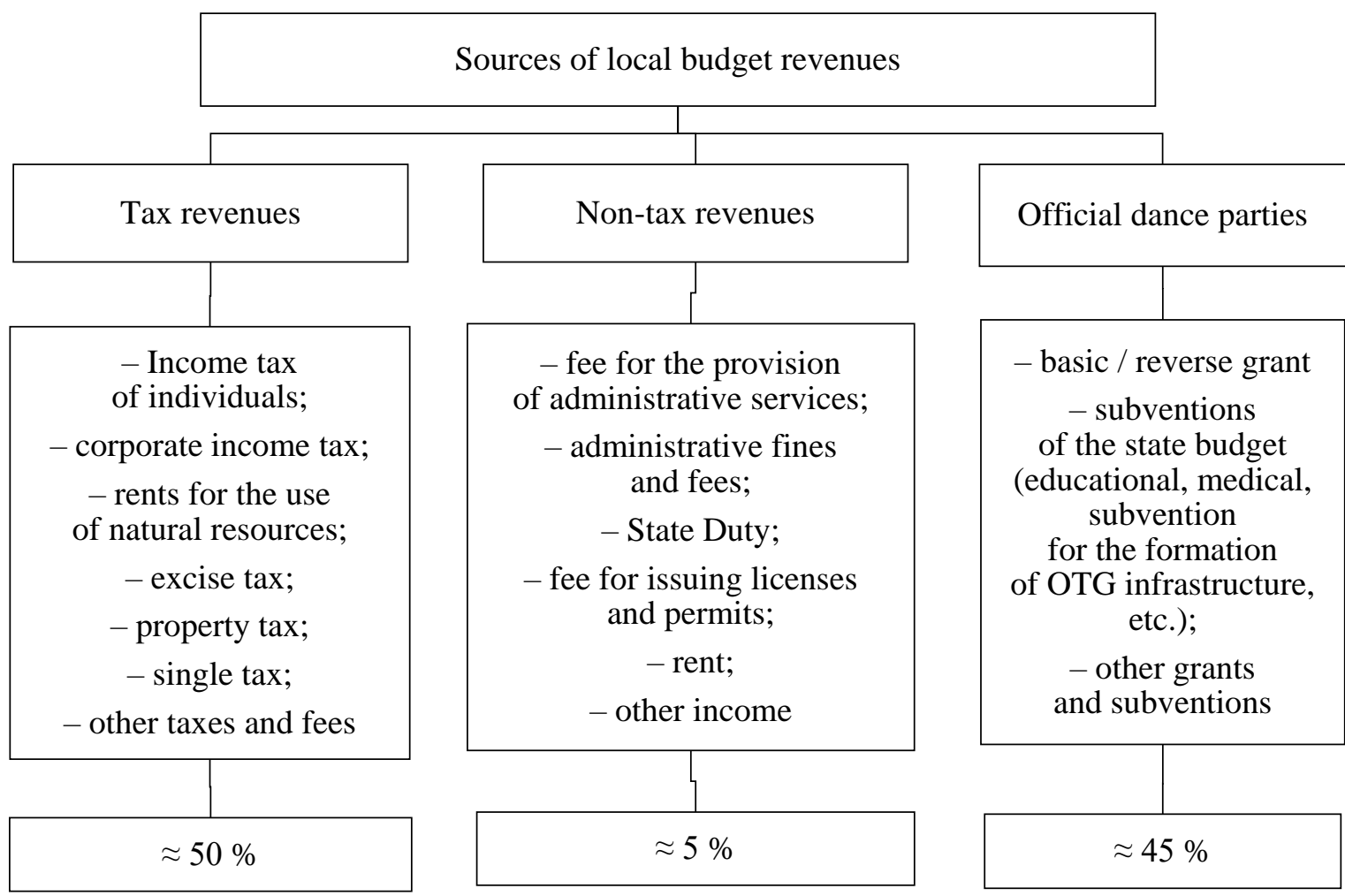

Fig. 2. Sources of local budget revenues

Source: compiled by the author

${ }^{1}$ Державна казначейська служба України (2020). Звіти про виконання місиевих бюджетів Украӥни за 2015-2019 рр. <http://treasury.gov.ua/> (2020, October, 29). 
The analysis of the revenue side of local budgets shows that despite the announced course of financial decentralization and the effect of intergovernmental horizontal equalization, the share of intergovernmental transfers in the structure of local revenues remains significant and requires effective directions to increase the share of local budget revenues.

We are not saying that intergovernmental transfers are not needed. They are definitely needed because they are an important mechanism for inter-budgetary regulation and enable the entire population to be provided with public services equally and enable them to implement important socio-economic programs. However, the mechanism of intergovernmental transfers and their volume should be brought to the level of European countries under the conditions of decentralization policy, taking into account regional specifics.

Increasing the revenue side of local budgets requires solving certain general problems that will contribute to the growth of their revenues not through intergovernmental transfers. Common to all regions are the problems of wage shadowing. This problem requires intervention at the state level. The shadowing of incomes is reflected in the statistics of incomes and expenditures of the population, and although the gap between expenditures of the population and incomes has narrowed over the last decade, it still remains significant.

The de-shadowing of household incomes will significantly increase the revenue side of local budgets, as the personal income tax accounts for a larger share of local budget tax revenues. Also, there is a debt to local budgets for the transfer of income tax from economic entities in the regions ${ }^{1}$. Most often, such debts are large enterprises in the regions, which, in turn, have the strongest impact on the revenue side and the plan of tax revenues.

In addition to income tax arrears, local budgets have arrears of land tax, personal income tax, real estate tax and excise tax. Such debts to local budgets provoke not only non-fulfillment and timely non-filling of local budgets, but also affect the expenditures and financing of socio-economic projects in the regions.

Fiscal regional policy requires certain steps to improve the efficiency of its operation, which are:

- optimization of taxation taking into account the principles of fiscal regional policy in order to more effectively ensure the socio-economic development of regions;

- increasing the level of influence of local authorities on the process of generating local budget revenues;

- improving the system of real estate tax administration by conducting a monetary valuation (revaluation) of land and inventory taking into account the current market situation, the use of tax benefits in the form of real estate tax offsets due to income tax liabilities in order to avoid double taxation and increasing the incentives of business entities;

- introduction of new mechanisms and measures of control over the process of use, formation and effective distribution of budget resources by local authorities by the public using modern information technologies, which will ensure greater transparency and efficiency of budget funds use by local authorities;

- increasing the competence of the local authorities' management in relation to fiscal regional policy in the context of decentralization in the direction of increasing the level of local budget management efficiency;

- regulatory regulation of additional sources of revenue to the local budget by expanding their own sources of filling budgets (tariff incentives for rational treatment of waste disposal, fees for advertising within cultural and historical centers, etc.);

- encouraging local authorities to increase the tax base and increase the level of mobilization and efficiency of financial resources and the proper formation of local budget revenues, which increases the efficiency of socio-economic development of administrative-territorial units by changing regulations on the share of local budget revenues without transfers the structure of the consolidated budget at the level of not less than $30 \%$;

- the development of mechanisms for interested regions and municipalities belonging to grant aimed at increasing local revenues;

- introduction of motivational mechanisms for regions and territorial communities that are donors of transfers in the horizontal alignment of inter-budgetary relations, to increase the revenue side of budgets.

\footnotetext{
${ }^{1}$ Сидор, І. П. (2019). Міжбюджетні трансферти в системі доходів місцевих бюджетів: сучасний стан та напрями вдосконалення. Інфраструктура ринку, 32, 363-370.
} 
Conclusions from the study. Thus, the proposed areas for improving the efficiency of fiscal regional policy will increase the level of social needs and economic development, taking into account its principles, namely: systemic, fair, local, regional equality, sufficiency, stability, flexibility and regional efficiency. In turn, improving the efficiency of fiscal regional policy in the context of decentralization becomes the main prerequisite for building a democratic state and directing efforts to improve the socio-economic life of the population. Decentralization in Ukraine is aimed at encouraging local authorities to implement effective fiscal policies to ensure a high level and proper access of citizens to public goods by improving the regulatory framework for intergovernmental transfers in the context of avoiding the negative impact of certain socio-economic factors. Improving the effectiveness of fiscal regional policy has a synergistic effect on the development of regions and local communities, as increasing the level of socio-economic development provides an increase in tax revenues to local budgets. In turn, the increase in tax revenues requires the involvement of other institutions, infrastructural elements of administrative-territorial units and regional development instruments that can become effective in ensuring the local development of regional entities.

\section{References:}

1. Tulchynska, S. O. (2009). Intelektualno-innovatsiina modernizatsiia ekonomiky Ukrainy: teoretyko-metodolohichni aspekty [Intellectual-innovative modernization of the economy of Ukraine: theoretical and methodological aspects]. Kyiv, NTUU «KPI», [in Ukrainian].

2. Vakhnovska, N. A. (2018). Fiskalna polityka v konteksti finansovoi konverhentsii sotsialno-ekonomichnoho rozvytku rehioniv Ukrainy [Fiscal policy in the context of financial convergence of socio-economic development of the regions of Ukraine]. Ekonomichnyi forum [Economic forum], 2, 271-276. [in Ukrainian].

3. Kuzheliev, M. O., Nechyporenko, A. V. (2019). Finansovi instrumenty stymuliuvannia rehionalnoho rozvytku: praktyka vykorystannia v Ukraini [Financial instruments of stimulation of regional development: practice of use in Ukraine]. Kyiv. [in Ukrainian].

4. Rodchenko, V. B., Prus, Yu. I. (2016). Vplyv reformy fiskalnoi detsentralizatsii na mistsevi biudzhety Ukrainy [The impact of fiscal decentralization reform on local budgets of Ukraine]. Sotsialna ekonomika [Social economy], 1, 59-68. [in Ukrainian].

5. Tulchynska, S. O. (2014). Perspektyvy ta dominanty rozvytku intelektualno-innovatsiinoi systemy rehioniv Ukrainy [Perspectives and dominants of development of intellectual-innovative system of regions of Ukraine]. Kherson: PP Vyshemyrskyi V.S.[in Ukrainian].

6. Fedoryshyna, L. I., Zhmurko, I. V. (2016). Sotsialna i fiskalna polityka derzhavy: vplyv na rehionalnomu rivni [Social and fiscal policy of the state: influence at the regional level]. Hlobalni ta natsionalni problemy ekonomiky [Global and national economic problems], 12, 468-473. [in Ukrainian].

7. Derzhavna kaznacheyska sluzhba Ukrayiny (2020) [State Treasury Service of Ukraine (2020).]. Zvity pro vykonannia mistsevykh biudzhetiv Ukrainy za 2015-2019 rr. [Reports on the implementation of local budgets of Ukraine for 2015-2019]. <http://treasury.gov.ua/> (2020, October, 29). [in Ukrainian].

8. Aleskerova, Yu.V. (2016). Fiskalnyi mekhanizm sotsialno-ekonomichnoi sfery yak skladova chastyna finansovoho mekhanizmu derzhavy [Fiscal mechanism of the socio-economic sphere as an integral part of the financial mechanism of the state]. Prychornomorski ekonomichni studii [Black Sea Economic Studies], 3, 98-101. [in Ukrainian].

9. Sydor, I. P. (2019). Mizhbiudzhetni transferty v systemi dokhodiv mistsevykh biudzhetiv: suchasnyi stan ta napriamy vdoskonalennia [Interbudgetary transfers in the system of local budget revenues: current status and areas for improvement]. Infrastruktura rynku [Market infrastructure], 32, 363-370. [in Ukrainian]. 